\title{
Marketing Incheon: Gateway for Seoul, Northeast Asia and the World
}

\author{
Peter J. Rimmer
}

\begin{abstract}
New economic geography theorists, who have revived the importance of local roots and highlighted the significance of cities as a source of international competitiveness, have spurred the global marketing of Incheon. An examination of the new economic geography literature examines the nature of the new localism based on clusters, involving spatial proximity and concentrated face-to-face transaction, agglomeration economies and local knowledge networks. The territorial expression of these ideas is evident in competitive cities and knowledge cities. Both types of cities are embodied in civic attempts to market Incheon as an international city through the development of the international harbor and international airport and a knowledge city at Songdo. As there is no reference to Incheon in the place marketing literature there is a need to market it as SeoulIncheon and itemize the Capital Region's key assets and strategic advantages, including logistics and Pentaport - five ports in one - to build a presentation that attracts foreign direct investment and foreign expertise and provokes an energizing debate on the Korean Government's plan to position the country as the hub for international commerce in Northeast Asia. Critics of this place marketing approach designed to make Incheon a prosperously middle-class city suggest more evidence is needed before it can be assumed firms locate in cities as a base for export activities to boost their competitiveness. Perhaps there is need to give up the preoccupation with the local focus in cluster analysis and give equal attention to global connections.
\end{abstract}

Keywords: Agglomeration Economies, Clusters, Competitive Cities, Knowledge Cities, New Economic Geography, Incheon, Local Networks, Place Marketing, Seoul.

\section{INTRODUCTION}

The global marketing of places has been boosted by the World Bank's study on Local Dynamics in an Era of Globalization (Yusuf, Wu and Evenett, 2000). The study's editors see urbanization being spurred by local dynamics and the integration of cities into the

- Peter J. Rimmer is Emeritus Professor and Visiting Fellow, Division of Pacific and Asian History, Research School of Pacific and Asian Studies, The Australian National University, Canberra, ACT, Australia and Adjunct Professor of Urban Development and Housing, Centre for Developing Cities, University of Canberra, Canberra, ACT, Australia. E-mail: pjrimmer@actewagl.net.au 
world economy opening the door to faster growth by attracting foreign funds and expertise. How interdependencies across space, time and issues evolve is of critical importance because half of the world's population was urban in 2000 and forecasts expect this figure to reach two-thirds by 2025 (UN, 2003). Given this scenario, the editors of the World Bank study argue that the 'new economic geography literature' that analyses the role of city-regions in a global economy could grow in importance.

This observation raises a series of issues: what are the key features of the new economic geography literature; how can the literature's emphasis on cities as the sources of international competitiveness be demonstrated; and are there any analytical problems with the place marketing approach, or, more specifically, is there a connection between the prosperity of cities and the prosperity of corporations? Finally, what are the policy implications of any challenge to place marketing?

These issues are addressed by initially reviewing the new economic geography literature. Then the competitiveness of cities is illustrated with reference to Incheon Metropolitan City, Korea, and to the encompassing Seoul metropolitan area. Concerns with the place marketing approach are then addressed and their likely impact on policy considered.

\section{NEW ECONOMIC GEOGRAPHY LITERATURE}

The establishment of a link between urbanization and capital accumulation resulted in urban economic theory no longer assuming local linkages were a critical factor (Castells, 1997; Massey, 1984; Harvey, 1985). Civic leaders were concerned that international linkages associated with transnational corporations would dwarf localized connections. Their anxieties were calmed when the new economic geography theorists were able to revive the importance of the urban economy's local roots and proceed to highlight the significance of cities as sources of international competitiveness. As Masahisa Fujita, Paul Krugman and Anthony Venables (1999) have provided an overview of the new economic geography in their book on The Spatial Economy: Cities, Regions, and International Trade, attention here can be focused on those elements that are pertinent to the new localism (Figure 1). 
Figure 1. The new economic geography

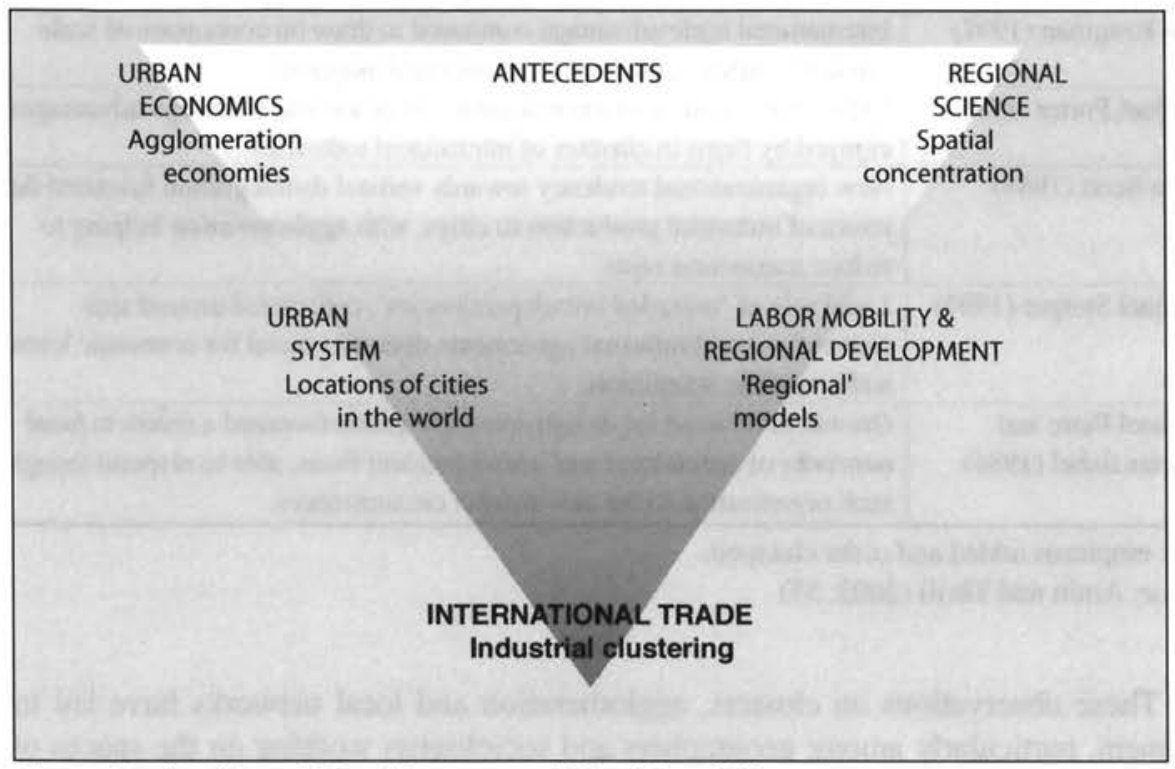

Source: Derived from Fujita, Krugman and Venables, 1999.

\section{The New Localism}

A succinct review of the new localism by Ash Amin and Nigel Thrift (2002) highlights the importance of clusters, agglomeration and local networks (Table 1). Clusters are seen by Paul Krugman (1991) and Michael Porter (1995) to offer economies of scale to interrelated industries, which, in turn, allow the urban base to be a source of international competitiveness. Agglomeration, according to Allen Scott (1988), helps reduce transaction costs for city-based industrial production, a notion later extended by Michael Storper (1997) to emphasize the local role of 'untraded interdependencies' stemming from informal arrangements. Local networks, comprising specialized and interdependent firms, can, as described by Michael Piore and Charles Sabel (1984), accommodate the demand for design-intensive goods. 
Table 1. The New Localism

\begin{tabular}{l|l}
\hline Paul Krugman (1991) & $\begin{array}{l}\text { International trade advantage continued to draw on economies of scale } \\
\text { offered to firms in clusters of interrelated industries }\end{array}$ \\
\hline Michael Porter (1995) & $\begin{array}{l}\text { Urban base a source of international competitiveness through advantages } \\
\text { enjoyed by firms in clusters of interrelated industries }\end{array}$ \\
\hline Allen Scott (1988) & $\begin{array}{l}\text { New organizational tendency towards vertical disintegration favoured the } \\
\text { return of industrial production to cities, with agglomeration } \text { helping to } \\
\text { reduce transaction costs. }\end{array}$ \\
\hline Michael Storper (1997) & $\begin{array}{l}\text { Local role of 'untraded interdependencies', constituted around tacit } \\
\text { conventions and informal agreements deemed crucial for economic learning } \\
\text { and economic adaptation. }\end{array}$ \\
\hline Michael Piore and & $\begin{array}{l}\text { Growth in demand for design-intensive goods favoured a return to local } \\
\text { networks of specialized and interdependent firms, able to respond though } \\
\text { such organization to the new market circumstances }\end{array}$ \\
\hline
\end{tabular}

Note: emphasis added and order changed.

Source: Amin and Thrift (2002: 55)

These observations on clusters, agglomeration and local networks have led to the argument, particularly among geographers and sociologists working on the spaces of the post-mass production economy, that the new competition will be between economic systems based on city-regions. This assumption has led to the identification of competitive city-based regions in Northeast Asia (Figure 2). 
Figure 2. City-regions in Northeast Asia with populations over 2 million, 2000

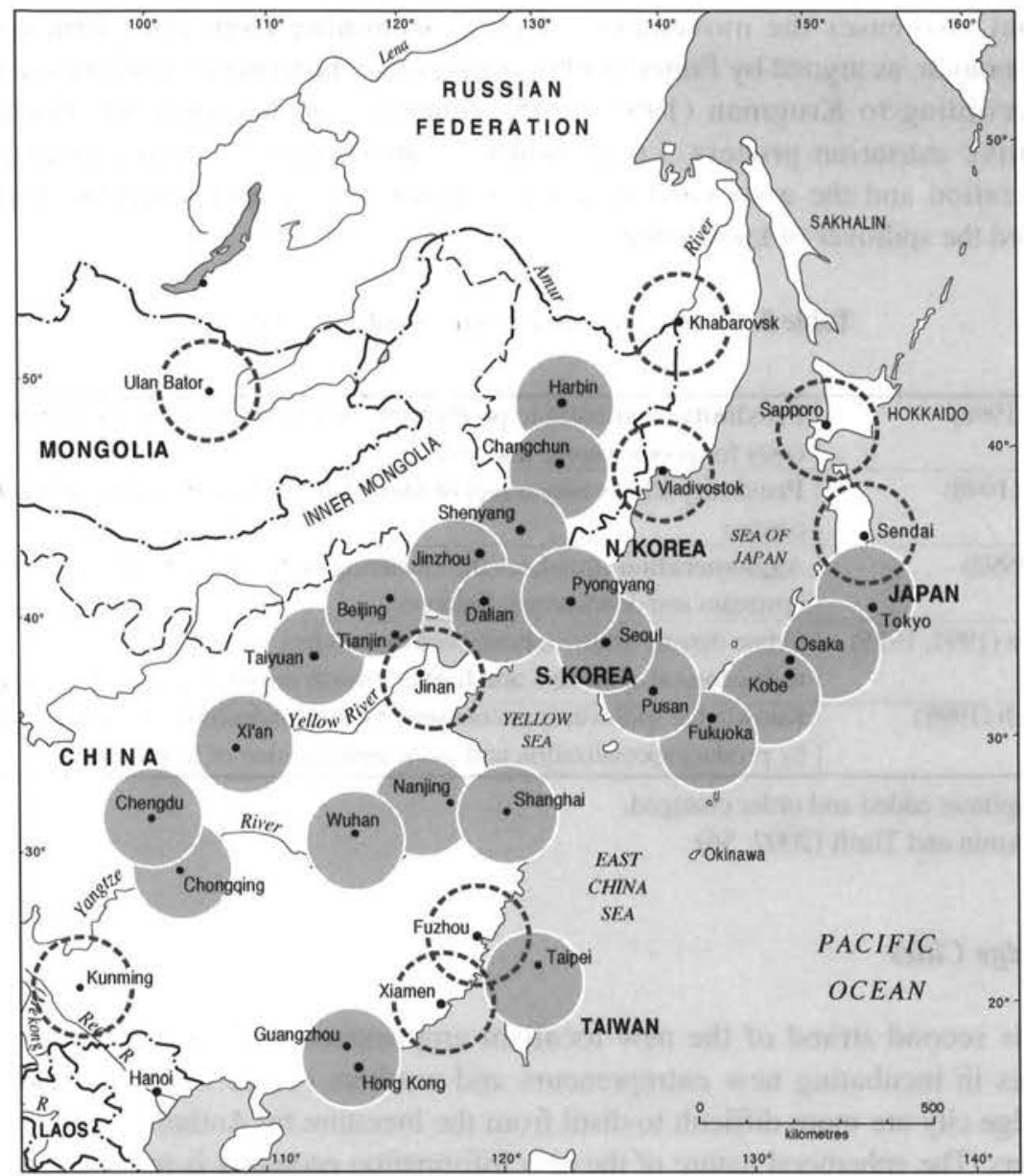

Source: Rimmer and Jun, 2000.

The new localism restored the confidence of local (and national) communities that they could become prosperous and secure within a borderless world. Indeed, further efforts to develop the local community would generate new capabilities to address opportunities offered by globalization. The new world order was biased in favour of places rather than economic actors. This shift in emphasis led urban governments to center policies on clusters, involving spatial propinquity and concentrated face-face transactions, agglomeration economies and local knowledge networks. Under the rubric of competitive cities and knowledge cities, the new economic geography theorists have elaborated the territorial assumptions underpinning these policies.

\section{Competitive Cities}

Urban agglomerations are seen as the sources of international competitiveness based 
on proximity, agglomeration and localization (Table 2). Proximity, according to Glaeser (1998), not only contributes to productivity by reducing the transport and communications costs but also eases the movements of ideas stemming from inter-firm contacts. Agglomeration, as argued by Porter (1995), triggers the clustering of industries: a process that, according to Krugman $(1991,1995)$ generates further spin-offs through the cumulative causation process. Local industrial atmospherics, arising from product specialization and the associated division of labor, has, as explained by Andretsch, facilitated the spillover of knowledge.

Table 2. Cities as sources of international competitiveness

\begin{tabular}{l|l}
\hline Glaeser(1998) & $\begin{array}{l}\text { Proximity contributes to productivity be reducing transport and transaction } \\
\text { costs for goods, people and ideas }\end{array}$ \\
\hline Glaeser (1998) & $\begin{array}{l}\text { Proximity allows easy travel of ideas due to labour mobility and interfirm } \\
\text { contact }\end{array}$ \\
\hline Porter (1995) & $\begin{array}{l}\text { Agglomeration stimulates the clustering of interrelated industries with } \\
\text { upstream and downstream linkages }\end{array}$ \\
\hline Krugman (1991, 1995) & $\begin{array}{l}\text { Urban density allows labour pooling, product specialization, } \\
\text { technological spillovers and further growth through cumulative causation }\end{array}$ \\
\hline Andretsch (1998) & $\begin{array}{l}\text { Knowledge spillover is encouraged by local industrial atmosphere produced } \\
\text { by product specialization and associated division of labour }\end{array}$ \\
\hline
\end{tabular}

Note: emphasis added and order changed.

Source: Amin and Thrift (2002: 56).

\section{Knowledge Cities}

This second strand of the new localism emphasizes the importance of cultural resources in incubating new entrepreneurs and workers (Table 3). The bases of the knowledge city are more difficult to distil from the literature by Anthony Giddens (1994) and others. The ephemeral nature of the new information economy is reflected in the less clear-cut combination of the weightless economy, 'knowlegeability' in everyday decisions, new sources of competitive advantage stemming from innovation, design and branding, risky markets, the job-loose knowledge entrepreneur, the peripatetic wired subject and reliance on teams of people to engender trust. ${ }^{1}$ Nevertheless, city leaders are attracted by the promise of untold urban wealth and, even if not seeking a freestanding version of the knowledge city, desire to integrate the concept into their overall plan for their city-region.

\footnotetext{
' Probably, connectivity, standardization and flows offer a better basis for discussing 'knowledge cities'.
} 
Table 3. Knowledge city

\begin{tabular}{l|l}
\hline $\begin{array}{l}\text { Coyle, 1997; } \\
\text { Quah, 1997 }\end{array}$ & Weightless economy based on intangible goods and information \\
\hline Giddens, 1994 & $\begin{array}{l}\text { Incorporation of education, learning and knowledgeability into the everyday } \\
\text { decisions of a reflexive society }\end{array}$ \\
\hline Leadbeater, 1999: 10 & $\begin{array}{l}\text { New sources of competitive advantage - innovation, design, branding, know- } \\
\text { how }\end{array}$ \\
\hline Burton-Jones, 1999 & $\begin{array}{l}\text { Risky markets or rapidly changing standards which require a culture of continual } \\
\text { learning }\end{array}$ \\
\hline $\begin{array}{l}\text { Leadbeater, 1999; } \\
\text { Sennett, 1998 }\end{array}$ & $\begin{array}{l}\text { New protagonists are the knowledge entrepreneur adapting specialized know- } \\
\text { how for different media(e.g. cooking skills for books, magazines and TV), the } \\
\text { fast paced knowledge working with no fixed job and lifelong employment }\end{array}$ \\
\hline $\begin{array}{l}\text { Flores and Gray, } \\
\text { 2000:21 }\end{array}$ & $\begin{array}{l}\text { The wired subject who animated by virtues and boldness and risk taking flits } \\
\text { form one project to project in the age of new work without careers }\end{array}$ \\
\hline Leadbeater. 1999:13 & $\begin{array}{l}\text { In the new economy trust and complementarity will drive success, since 'ideas } \\
\text { for new products usually emerge from teams of people drawing together different } \\
\text { expertise' }\end{array}$ \\
\hline
\end{tabular}

Source: Amin and Thrift (2002: 59-60).

\section{MARKETING INCHEON}

Ideas stemming from competitive cities and knowledge cities are evident in attempts by leaders of Incheon Metropolitan City to market the urban area, with a population of 2,6 million in an area of $960 \mathrm{~km}^{2}$, as if it were a product (IMC, 2004). In a bid to capture the new global geography the city is being redesigned and rebuilt as part of Incheon Vision 21 by developing:

- a [competitive] international city, which is being planned as an 'outpost of globalization' through the development of the international harbor and international airport; and

- an ultra-modern new town [knowledge city] intended for the $21^{\text {st }}$ century information era (see Songdo Intelligent City below). ${ }^{2}$

Despite this vision there is no mention of Incheon in Marketing Asian Places: Attracting Investment, Industry and Tourism to Cities, States and Nations, a comprehensive analysis by Philip Kotler and others (2002), though there are several references to Seoul. This omission suggests there is a pressing need to itemize the Metropolitan City's key assets and strategic advantages in an image building presentation, both as an exercise in place marketing designed to attract foreign direct investment (FDI)

2 The other four features of Incheon Vision 21 are: Cultural City, Healthy City, Ocean City and Network City. 
and to provoke an energizing debate. ${ }^{3}$

Taking my cues from the marketing of Chicago (O'Connor, 2001, 2003), this inquiry seeks to initiate a strategic discussion about positioning Seoul-Incheon in the emerging new global geography. Attention is focused initially on identifying key drivers and outlining the economic situation. The analysis is based on the assumption that the direction of the world economy has not been fully mapped and that key variables guiding its trajectory are still largely unidentified. Assuming this to be the case, the surest strategy for Seoul-Incheon to follow towards global emergence is economic diversification coupled with the widest possible social diversity. Human capital remains the paramount force driving the global economy, while both location and infrastructure remain significant. This guiding philosophy is predicated upon the future being about regional blocs, multinational corporations (MNCs) and metropolitan city-regions rather than weakening nation states (Porter, 1990; Pierce, 1993; Ohmae, 1995; Kanter, 1995). Urban lifestyles will rule! Global-city regions are emerging, buoyed by increased worldwide economic linkages stemming from newly rising economies in Asia and Eastern Europe, more foreign direct investment, increasing urbanization and recognition of the economic potential of the southern hemisphere.

Within this global context Incheon Metropolitan City is committed to playing a pivotal role in the implementation of the Korean Government's policy designed to position the country as the hub for international commerce in Northeast Asia. The entire project is designed to drive Korea into high value added services to provide an average annual per capita income of US\$20,000 and compensate for the loss of jobs to neighboring countries with cheaper labor. As a late starter in the race to become a regional logistics hub against Beijing-Tianjin, Hong Kong, Shanghai, Singapore and Taipei, the Korean government is conscious of the need to capitalize on the search by global firms for opportunities to trade with or invest in China or Japan. If the Korean government does the right thing now, Seoul-Incheon will be one of the top ten or twenty metropolitan centers in an emerging world order twenty years hence. If the Korean government fails, it will be because the vision offered by the leaders did not comprehend the changed structure of the global economy and identify strategies for making the transition to the new world order.

As a means of coping with the changing global environment the Korean government designated Incheon in 2003 as the country's first Free Economic Zone (FEZ) ahead of those later located at Busan and Gwangyang Bay in the south of the country. ${ }^{4}$ The

3 The study is important because Tae Oum and Kichan Park and others (2002: 378) have observed that 'the Seoul-/Incheon area has many strong points but [is] strategically not appealing to MNCs [multinational corporations]'.

4 In the Incheon Free Economic Zone foreign investors are exempt from income and corporate taxes during the first three years of their operations; a 50 per cent deduction is available for the fourth and fifth years. Imports are tariff free. English will be used in administrative services and all official documentation. Foreign firms will be exempt from restrictions that apply to firms seeking sites in the National Capital Region (Jun, 2003). 
US\$168 billion Incheon FTZ project comprises three separate districts within Incheon Metropolitan City covering $209 \mathrm{~km}^{2}$ - the Cheongra reclaimed area, Songdo and Yeongjong surrounding Incheon airport. ${ }^{5}$ These areas are earmarked for major projects between now and 2020:

- Cheongra $\left(18 \mathrm{~km}^{2}\right)$ for international financial centers, tourism and leisure complexes, the floral complex and global entertainment;

- Songdo Intelligent City $\left(53 \mathrm{~km}^{2}\right)$ for knowledge-based industry including information technology (IT), bio-technology (BT) and nano-technology (NT), research and development and international business centers (Table 4) $;$; and

- Yeongjong (138km2) for global logistics centers, tourism and leisure. ${ }^{7}$

A more generous definition of the FEZ to include continuous areas of the cities of Shiheung, Ansan, Gimpo and Pyongtaek would have provided a more functional cityregion comparable to Shanghai (Jun, 2003). Nevertheless, Incheon Metropolitan City is poised to be the gateway for Seoul, Northeast Asia and the rest of the world.

Table 4. Construction of Songdo New City (Songdo Inpia)

\begin{tabular}{|c|c|c|c|}
\hline $\begin{array}{l}\text { Construction } \\
\text { District }\end{array}$ & $\begin{array}{c}\text { Area } \\
\text { mn } \\
\text { pyeongs }\end{array}$ & $\begin{array}{l}\text { Project } \\
\text { Period }\end{array}$ & $\begin{array}{l}\text { Major } \\
\text { Facilities }\end{array}$ \\
\hline First & 1.3 & $1996-2008$ & $\begin{array}{l}\text { Incheon trade center, convention, international trade and finance } \\
\text { complex, resident and commercial complex }\end{array}$ \\
\hline $\begin{array}{l}\text { Second \& } \\
\text { Fourth }\end{array}$ & 1.76 & $1994-2003$ & $\begin{array}{l}\text { Media valley, techno park, multimedia support facility, } \\
\text { residential complex }\end{array}$ \\
\hline Third & 0.76 & 1996-2008 & International business complex, theme park, culture complex \\
\hline $\begin{array}{l}\text { Fifth \& } \\
\text { Sixth }\end{array}$ & 0.53 & 2005-2011 & $\begin{array}{l}\text { Culture complex, education and research } \\
\text { complex, and lake park }\end{array}$ \\
\hline
\end{tabular}

Note: pyeong

Source: IMC (2004).

\section{Capital Region}

As it is difficult to separate Incheon from Seoul Metropolitan City, ranked twentieth among the world's urban agglomerations by the United Nations (UN, 2001), and the

5 The combined central and local government investment is US\$12 billion; the balance is expected to come from the private sector.

6 New Songdo city is being developed by the US-based Gale Company (developer and marketing agent) in agreement with POSCO E \& C (construction manager) IFEZA, 2004).

7 By 2008 a six-lane, 10-km bridge will connect Songdo to Incheon International Airport. 
encompassing Gyeonggi province, all three are grouped together as the Capital Region to discuss population, employment and gross regional product. With less than 12 per cent of South Korea's land area, the Capital Region accounted for over 46 per cent of the national population in 2000 - a continuous trend from 20.8 per cent in 1960 (Table 5).

Table 5. Actual and projected population of Korea; Seoul, Incheon, Gyeonggi and Capital Region, 1960-2015

\begin{tabular}{|c|c|c|c|c|c|c|c|c|c|c|c|c|}
\hline & \multicolumn{9}{|c|}{ Actual } & \multicolumn{3}{|c|}{ Projected } \\
\hline & 1960 & 1965 & 1970 & 1975 & 1980 & 1985 & 1990 & 1995 & 2000 & 2005 & 2010 & 2015 \\
\hline Korea & 25.0 & 29.2 & 31.5 & 34.7 & 37.4 & 40.5 & 43.2 & 44.6 & 46.1 & 48.3 & 49.6 & 50.3 \\
\hline Seoul & 2.5 & 3.8 & 5.4 & 6.9 & 8.4 & 9.6 & 10.6 & 10.2 & 9.9 & 9.9 & 9.9 & 9.7 \\
\hline Incheon & 0.4 & 0.5 & 0.6 & 0.8 & 1.1 & 1.4 & 1.8 & 2.3 & 2.5 & 2.6 & 2.8 & 2.9 \\
\hline Gyeonggi & 2.3 & 2.6 & 2.7 & 3.2 & 3.8 & 4.8 & 6.2 & 7.6 & 9.0 & 10.1 & 11.3 & 12.1 \\
\hline Capital region & 5.2 & 6.9 & 8.7 & 10.9 & 13.3 & 15.8 & 18.6 & 20.1 & 21.4 & 22.6 & 24.0 & 24.7 \\
\hline Percent & 20.8 & 23.6 & 27.7 & 31.5 & 35.5 & 39.1 & 42.8 & 45.2 & 46.3 & 46.7 & 48.4 & 49.1 \\
\hline
\end{tabular}

Source: KNSO (2004).

The Capital Region's share of establishments and workers is even more pronounced than that of population. As the nation's manufacturing leader, the Capital Region accounts for more than 50 per cent of the nation's manufacturing enterprises and almost 50 per cent of the nation's well-educated workforce (Table 6). This latter figure is exceeded in finance and insurance, real estate and business activities, comprising computer and related activities, research and development, professional, scientific and technical services and business support services. ${ }^{8}$

Table 6. Capital Region's share of establishments and employment for selected categories, 2002

\begin{tabular}{l|c|c|c|c|c|c}
\hline & National & Seoul & Incheon & Gyeonggi & \multicolumn{2}{c}{ Capital Region } \\
\cline { 2 - 7 } & million & million & million & million & million & per cent \\
\hline \hline Establishments & 0.898 & 0.230 & 0.040 & 0.135 & 0.405 & 45.1 \\
$\begin{array}{l}\text { Total } \\
\text { Manufacturing }\end{array}$ & 0.333 & 0.074 & 0.021 & 0.076 & 0.171 & 51.3 \\
\hline $\begin{array}{l}\text { Employment } \\
\text { Transport }\end{array}$ & 0.864 & 0.257 & 0.059 & 0.050 & 0.366 & 42.3 \\
$\begin{array}{l}\text { Total } \\
\text { Manufacturing }\end{array}$ & 14.608 & 3.806 & 0.723 & 2.721 & 7.273 & 49.8 \\
$\begin{array}{l}\text { Wholesale and } \\
\text { retail }\end{array}$ & 2.392 & 0.572 & 0.232 & 0.884 & 1.688 & 49.8 \\
$\begin{array}{l}\text { Finance and } \\
\text { insurance }\end{array}$ & 0.632 & 0.806 & 0.113 & 0.403 & 1.322 & 50.5 \\
$\begin{array}{l}\text { Education } \\
\text { Real estate }\end{array}$ & 1.059 & 0.227 & 0.024 & 0.083 & 0.334 & 52.8 \\
$\begin{array}{l}\text { Business } \\
\text { activities }\end{array}$ & 0.365 & 0.119 & 0.019 & 0.086 & 0.224 & 61.4 \\
\hline
\end{tabular}

Source: Calculated from KNSO (2004).

${ }^{8}$ In 2002 the Capital Region accounted for 61.5 per cent of R\&D expenditure and 68.5 per cent of researchers (MOST, 2004). 
The central government has been trying to curb this 'excessive' concentration of economic activity in the Capital Region since the 1960 s by selectively banning manufacturing plants, universities and colleges, and corporate headquarters locating within the Region's boundaries, while promoting the dispersal of jobs to other parts of the country. Apparently, more flexibility has been afforded high-tech enterprises. Without a relaxation of these restrictions, Kim (2001) argues that the Capital Region will be unable to capitalize on its strategic location between the vast markets of China and Japan in the world's fastest growing trading area of Northeast Asia without paying more attention to the positive benefits of urban agglomeration.

In 2002 the Capital Region economy is booming accounting for over 47.8 per cent of Korea's gross domestic product (GDP), a 2.3 per cent increase since 1996. When this figure is adjusted for purchasing power parity, the gross regional product of the Capital Region is estimated at US $\$ 390$ billion. This massive and complex economy is larger than many countries (Fig. 3). For example, the Capital Region was twice the size of Vietnam and four times the size of Singapore.

Figure 3. Gross regional product in the Asia-Pacific, c. 2000.

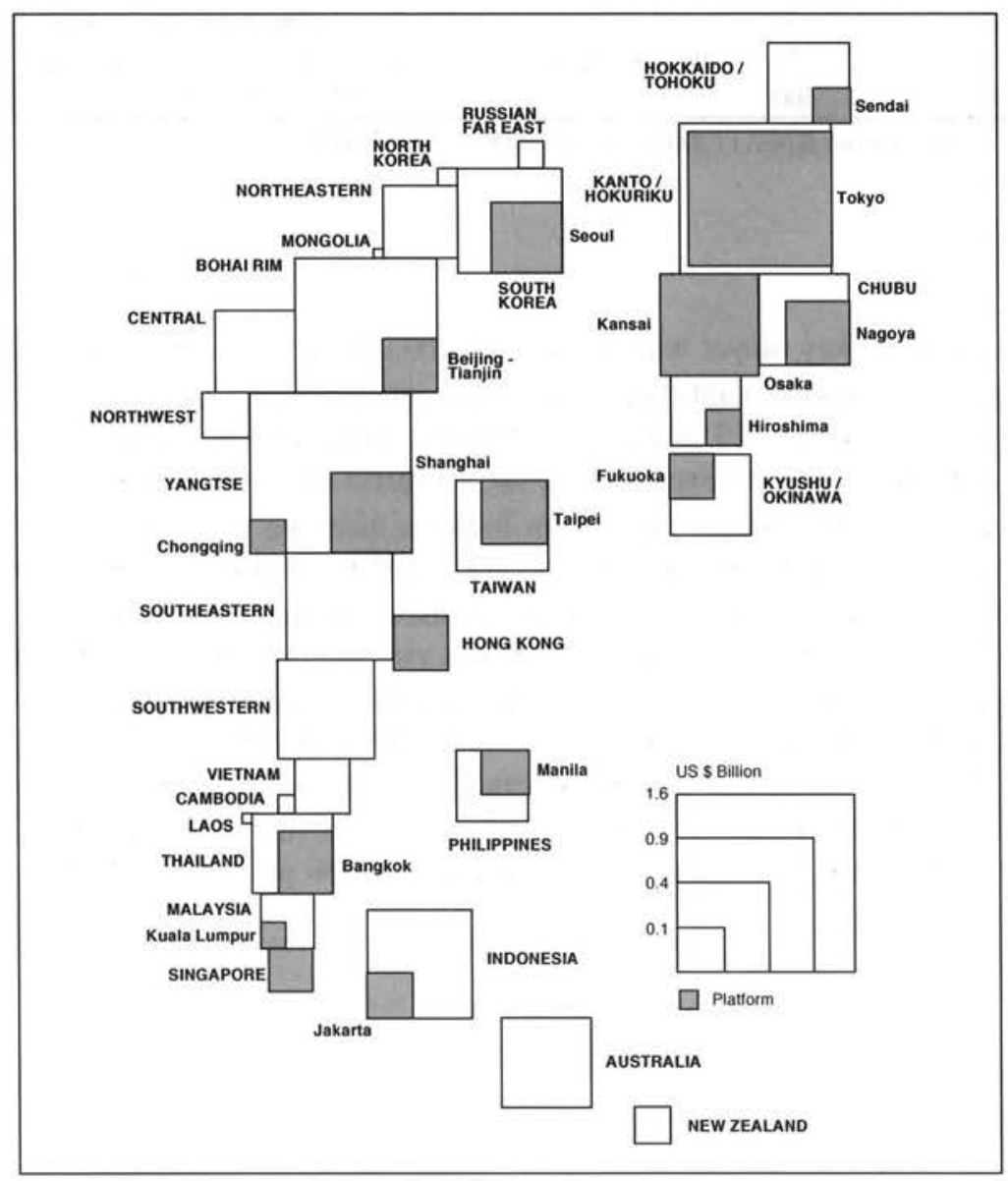


Within Northeast Asia, however, the Capital Region's gross regional product ranked the city-region behind Kanto, Chubu, and Kansai in Japan and the Lower Yangzte, Pearl River Delta and Bejing-Tianjin-Hebei in China (Table 7). This apparent shortfall has prompted the Korean government to focus attention on intensifying the Capital Region's inventory of regional and global linkages to meet the demand for agile and flexible logistics structures. These range from air, rail, road and sea transport and distribution parks and intermodal connections to intellectual/academic 'infrastructure', corporate headquarters and five-star hotels. Incheon is afforded a key role in this policy.

Table 7. Gross Domestic Product for City-regions in Northeast Asia based on purchasing power parity (PPP), 2002

\begin{tabular}{l|c|l|c|l|c}
\hline City & \$US bn & Mega-city & \$US bn & City-region & \$US bn \\
\hline \hline Tokyo & 581 & Tokyo-Yokohama & 783 & Kanto & 1237.0 \\
Osaka & 274 & Osaka-Kobe & 422 & Kansai & 512 \\
Shanghai & 237 & & & Lower Yangtze & 975 \\
Nagoya & 227 & Nagoya-Shizuoka & 330 & Chubu & 653 \\
Seoul & 178 & Seoul-Incheon & 214 & Seoul-Incheon-Gyeonggi & 390 \\
Hong Kong & 174 & & & Hong Kong-Guangdong & 714 \\
Beijing & 124 & Beijing-Jianjin & 208 & Beijing-Tianjin-Hebei & 470 \\
Singapore & 100 & & & & \\
\hline
\end{tabular}

Source: Calculated from KNSO (2004); NBSC (2003); SB (2004).

\section{Logistics}

Incheon is the key player with airlines. In 2003 Korea's air hub handled 20 million passengers - the world's tenth largest airport in international passengers (Table 8). The airport is the gateway to 119 international business destinations worldwide operated by fifty scheduled passenger airlines. There are 24 direct flights to Chinese cities. Within less than a 3 hours 30 minutes flight from Incheon there are 2 billion people - almost one-quarter of the world's population (Jun, 2003; Urban Development Authority, 2003). Located on a great circle route - the shortest distance between two locations - it is two hours quicker to fly from Sydney to London via Incheon than via Singapore. Not surprisingly, the Capital Region has become a business-meeting place - a center for conventions and tourism. It is possible to order breakfast in Mandarin, English and Japanese. Looking ahead, the Incheon International Airport is expected to be handling almost 81 million passengers per year in 2020, 478,000 flights and almost 8.4 million tonnes of cargo when Northeast Asia will account for 30 per cent of the world's gross national product. 
Table 8. Air traffic prospects at Incheon International Airport

\begin{tabular}{l|l|c|c|c|c|c}
\hline \multirow{2}{*}{ Category } & \multirow{2}{*}{ Unit } & \multirow{2}{*}{\begin{tabular}{c} 
Actual \\
\cline { 3 - 6 }
\end{tabular}} & & \multicolumn{5}{|c}{ Forecast } \\
\cline { 4 - 7 } & & $\mathbf{2 0 0 3}$ & $\mathbf{2 0 0 5}$ & $\mathbf{2 0 1 0}$ & $\mathbf{2 0 1 5}$ & $\mathbf{2 0 2 0}$ \\
\hline \hline Passengers & mill. & 20.00 & 30.80 & 46.29 & 63.12 & 80.77 \\
Cargo & mill. tonnes & 1.80 & 3.08 & 4.71 & 6.58 & 8.37 \\
Flights & thousand & 127 & 187 & 277 & 374 & 478 \\
\hline
\end{tabular}

Source: Park (2004); IIA (2004).

Already, Incheon International Airport is a world-class logistics hub. In 2003 it was the world's third largest cargo hub behind Hong Kong and Tokyo Narita handling over 1.84 million tonnes of cargo, with a significant transfer rate of 47 per cent for transhipment cargoes. ${ }^{9}$ An advanced computer system is able to handle 2.7 million tonnes per year with an expected capacity of 4,5 million tonnes by 2008 when there will be a second runway, and a planned capacity of 7 million tonnes by 2020 (Table 9). ${ }^{10} \mathrm{~A}$ $900,000 \mathrm{~m}^{2}$, customs free trade zone (FTZ) was created at the airport in 2002 as an attractive airport base for international logistics companies; it is expected to double in size $\left(1,980,000 \mathrm{~m}^{2}\right.$ by 2020$)$. The two home-based long haul cargo carriers - Asiana and Korean Air - are already based in this area and the Incheon International Airport is seeking to limit their domination in cargo handling by encouraging foreign cargo carriers, such as DHL and TNT, to locate there before the cargo terminal site opens in 2005. Low rents, tax breaks and relaxation of stringent regulations governing Capital Region sites are available as incentives for high-tech industry willing to locate in the Yeongdong area surrounding the international airport (Park, 2004). It is incumbent on the Incheon Metropolitan City to ensure that further land in Yeongdong is reserved for high-tech industry to capitalize on the winged city/aerotropolis phenomenon.

Table 9. Planned capacities at Incheon International Airport

\begin{tabular}{l|l|c|c|c}
\hline \multirow{2}{*}{} & \multirow{2}{*}{ Unit } & \multicolumn{2}{|c}{$\mathbf{1}^{\text {st }}$ Phase } & \multicolumn{2}{c}{$2^{\text {ss }}$ Phase } & Final \\
\cline { 3 - 5 } & & $\mathbf{1 9 9 2 - 2 0 0 1}$ & $\mathbf{2 0 0 2 - 2 0 0 8}$ & $\mathbf{2 0 2 0}$ \\
\hline \hline Passengers & million pax & 30.0 & 44.0 & 100.0 \\
Cargo & million tonnes & 2.7 & 4.5 & 7.0 \\
Flights & thousand & 240 & 410 & 650 \\
\hline
\end{tabular}

Source: Park (2004); IIA (2004).

9 In 2003 China and Japan accounted for 34.6 per cent of international air cargo, North America 28.3 per cent, Southeast Asia 18.3 per cent, Europe 15.2 per cent and others 3.6 per cent (Park, 2004).

${ }^{10}$ A study by Park and Kim (2002) suggests that Incheon International Airport ranked with the 'more competitive' New Hong Hong International Airport (HKG) and Singapore Changi (SIN). 
The Port of Incheon - another customs free trade zone - will be linked to the airport cargo area to create a joint logistics center that can handle maritime and air cargo simultaneously. Originally opened in 1883 , the Port has been handicapped by high tidal ranges. In 1974 the Inner Harbor's lock gate was developed and its Pier 4 became Korea's first container port. During the Cold War the container trade was centred on the Port of Busan, relegating Incheon to handling bulk cargoes. The revival of the trade with northeast China after the end of the Cold War has rejuvenated Incheon as a container port. Any restrictions on increasing port capacity in the Capital City region need to be lifted. This deregulation will enable new container berths to be incorporated in the South Port Area and the planned lock-less Songdo New Port, with new bulk berths being located in North Port. A throughput of 3.6 million twenty-foot equivalent units (TEUs) is expected on the completion of Songdo New Port, which would boost the Port of Incheon into the upper echelons of the world's container shipping league.

Looking ahead, there is strong backing for a deepwater port to maximize synergies with the airport to parallel developments in Rotterdam and Singapore (Oum, Park and others, 2002; Rimmer and Chang, 2004). The Holland Distribution Council (HIDC) - a recognized leader in freight logistics policy - bolsters this support by arguing locating airports and seaports adjacent to each other can capture significant economies of scale and scope. 'Supporting land transport infrastructure to nearby distribution centres enhances these economies of scale and scope' (DOTARS, 2002: 22). HIDC calls this 'The Gateway Clusters Concept' (see Kasteel, 2004).

Efforts are being made to transplant the concept of clusters in Incheon FEZ to attract the value added activities of global firms. Ten areas have been designated as distribution and logistics parks, which include both the airport FTZ and seaport FTZ (Table 10). These sites are available for value added logistics activities, notably cargo consolidation and allied businesses. Within the Incheon FEZ the logistics sites earmarked for the Cheongra and Songdo areas could be augmented with research parks, industrial parks and business parks. The area around the international airport in Yengjongdo would also be suitable for both and industrial and business parks (Jun, 2003). Efficient road access will be necessary to interconnect these sites. 
Table 10. Business parks in Incheon

\begin{tabular}{|c|c|c|c|c|c|}
\hline \multicolumn{2}{|c|}{ Business Park } & Location & $\begin{array}{c}\text { Area } \\
\text { million } \\
\mathbf{m}^{2}\end{array}$ & Developer & Activity \\
\hline \multicolumn{6}{|l|}{ Seaport } \\
\hline $\begin{array}{l}\text { Inner } \\
\text { Hinterland }\end{array}$ & Harbor & $\begin{array}{l}\text { Inner } \\
\text { Harbor } \\
\text { FTZ }\end{array}$ & 0.462 & $\begin{array}{l}\text { Incheon } \\
\text { Metropolitan City }\end{array}$ & $\begin{array}{l}\text { Support seaport } \\
\text { logistics }\end{array}$ \\
\hline $\begin{array}{l}\text { Northport } \\
\text { Park }\end{array}$ & Logistics & $\begin{array}{l}\text { Near } \\
\text { Northport }\end{array}$ & 2.545 & Hanjin & Distribution complex \\
\hline $\begin{array}{l}\text { Samsung/ } \\
\text { PSA }\end{array}$ & & $\begin{array}{l}\text { Near } \\
\text { Southport }\end{array}$ & 0.330 & $\begin{array}{l}\text { Samsung/ } \\
\text { PSA }\end{array}$ & $\begin{array}{l}\text { Support seaport } \\
\text { Logistics }\end{array}$ \\
\hline $\begin{array}{l}\text { Southport } \\
\text { Park }\end{array}$ & Business & $\begin{array}{l}\text { Near } \\
\text { Southport }\end{array}$ & 2.640 & $\begin{array}{l}\text { Ministry of Marine } \\
\text { Affairs \& Fisheries }\end{array}$ & $\begin{array}{l}\text { Logistics and } \\
\text { distribution complex }\end{array}$ \\
\hline Southport & Hinterland & Southport & 1.155 & KTOC & $\begin{array}{l}\text { Support seaport } \\
\text { logistics }\end{array}$ \\
\hline \multicolumn{6}{|c|}{ Airport/Free Economic Zone (Yeongjong) } \\
\hline Airport FT2 & & $\begin{array}{l}\text { Near cargo } \\
\text { terminals }\end{array}$ & 1.980 & $\begin{array}{l}\text { Incheon Int'l } \\
\text { Airport Corporation }\end{array}$ & $\begin{array}{l}\text { Logistics base for } \\
\text { MNC }\end{array}$ \\
\hline $\begin{array}{l}\text { Unseo } \\
\text { Park }\end{array}$ & Logistics & $\begin{array}{l}\text { Near } \\
\text { Incheon } \\
\text { Int'1 } \\
\text { Airport }\end{array}$ & 1.462 & $\begin{array}{l}\text { Incheon } \\
\text { Metropolitan City }\end{array}$ & $\begin{array}{l}\text { Airport logistics } \\
\text { district complex }\end{array}$ \\
\hline \multicolumn{6}{|c|}{ Other Free Economic Zones } \\
\hline $\begin{array}{l}\text { Cheongra B } \\
\text { Park }\end{array}$ & Business & $\begin{array}{l}\text { Cheongra } \\
\text { FEZ }\end{array}$ & 1.320 & $\begin{array}{l}\text { Ministry of Marine } \\
\text { Affairs \& Fisheries }\end{array}$ & $\begin{array}{l}\text { Logistics and } \\
\text { distribution complex }\end{array}$ \\
\hline $\begin{array}{l}\text { Cheongra F } \\
\text { Distributior }\end{array}$ & $\begin{array}{l}\text { loral } \\
\text { Park }\end{array}$ & $\begin{array}{l}\text { Cheongra } \\
\text { FEZ }\end{array}$ & 1.884 & $\begin{array}{l}\text { Ministry of } \\
\text { Agriculture }\end{array}$ & $\begin{array}{l}\text { Floral auctions and } \\
\text { distribution }\end{array}$ \\
\hline $\begin{array}{l}\text { Songdo } \mathrm{Ne} \\
\text { Logistics } \mathrm{P}\end{array}$ & $\begin{array}{l}\text { w Port } \\
\text { ark }\end{array}$ & $\begin{array}{l}\text { Songdo } \\
\text { FEZ }\end{array}$ & 4.793 & $\begin{array}{l}\mathrm{PH} \\
\text { Ministry of Marine } \\
\text { Affairs \& Fisheries }\end{array}$ & $\begin{array}{l}\text { Port logistics } \\
\text { distribution complex }\end{array}$ \\
\hline Total & & & 18.571 & & \\
\hline
\end{tabular}

Source: Derived from Park (2004: 23).

Obviously there is scope to develop intermodal transport because as the nation's busiest freight handler, the Capital Region possesses the largest rail hub and trucking center." Although the area is also the main generator and recipient of container cargoes, Busan and Gwangyang Bay in the south of the country rather than Incheon are the main designated container hubs. Nevertheless, the Capital Region is the nerve center of Korea in information and telecommunications with a strong software capability that could meet the demand of foreign companies for logistic professionals. Given the Capital Region's world rankings in transport and telecommunications (Table 4), it was but a short step for the Incheon Metropolitan City to envisage itself as a tri-port integrating an airport (Incheon International Airport), a seaport (Incheon International Port), and a teleport (Songdo Inpia) (Fig. 4).

"Once the railway connecting the two Koreas is reconstructed the triangle encompassing Seoul, Incheon and Gaesung is expected to undergo rapid development as a rail and trucking center. 
Table 11. World rankings, 2003

\begin{tabular}{c|l}
\hline Rank & Transport and communications \\
\hline \hline$\# 3$ & Airport in international cargo (Incheon) \\
$\# 4$ & Air cargo hubbing/transhipment ratio (Incheon) \\
$\# 10$ & International passenger airport throughput (Incheon) \\
$\# 19$ & Internet (Seoul) \\
$\# 74$ & Container port (Incheon) \\
\hline
\end{tabular}

Note: Figures for Internet and container port are for 2002.

Source: CI (2003); IIA (2004); Park (2004); TGI (2003)

Figure 4. Tri-port

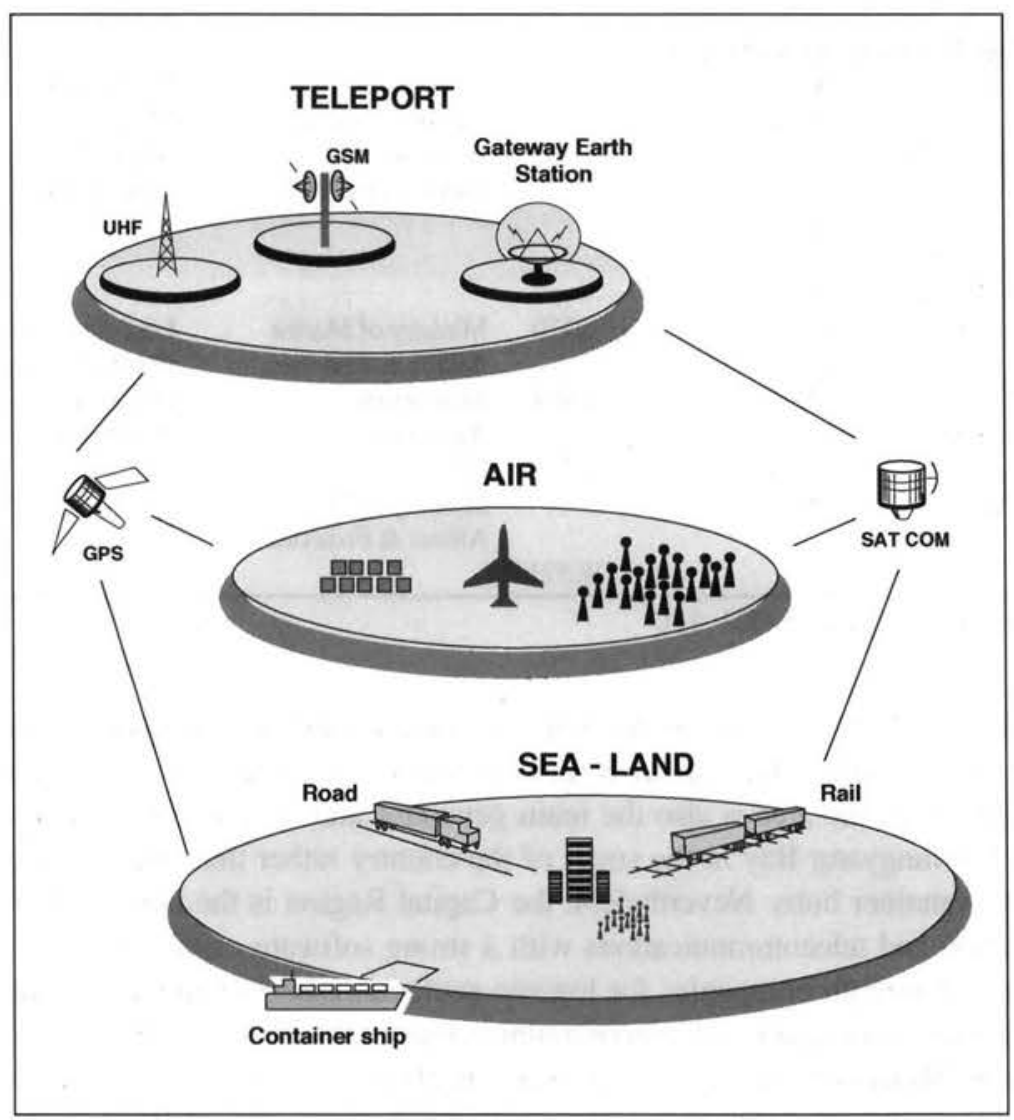

Source: based on Rimmer and Chang, 2004.

As the Incheon tri-port development replicates developments in Hong Kong, Singapore and Taiwan, the Ministry of Maritime Affairs and Fisheries (MOMAF) proposed in its vision for the twenty-first century - Ocean Korea 21 (OK 21) published 
in 2000 - to change the 'tele-port' into a 'technoport' and add a 'business port' and 'leisure port' to the original three components to create a Pentaport - five ports in one (Rimmer and Chang, 2004). This proposition has been accepted by Incheon Metropolitan City and work is proceeding apace on Pentaport's various components (Fig. 5). Already, Miller and Kim (2004) have provided a blueprint of the possibilities for the leisure port.

Figure 5. Pentaport

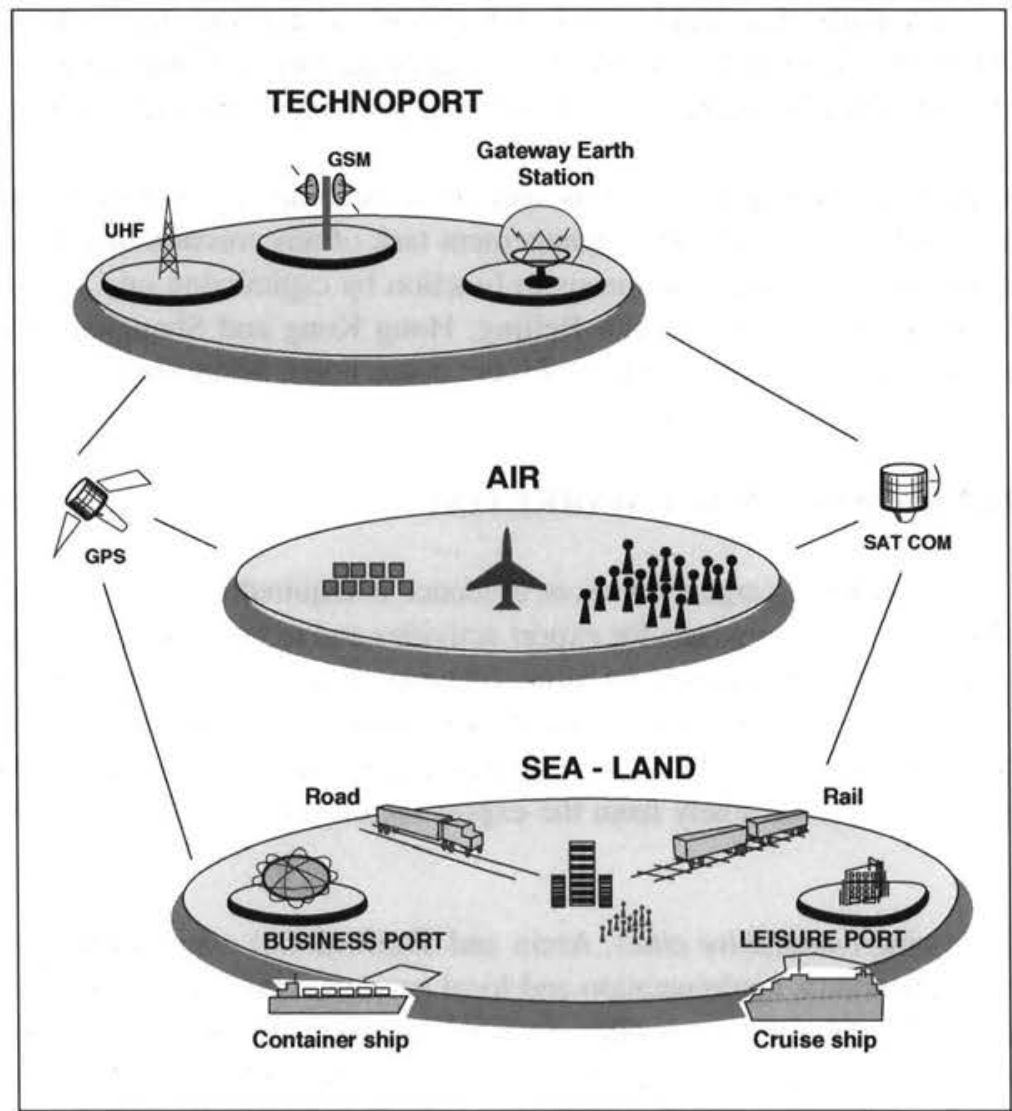

Source: Rimmer and Chang, 2004.

Complementing the Pentaport initiative has been the effort by the Korean government to develop skills in logistics. In particular, local universities in the Incheon Area have taken up this effort. For example, Inha University has created the Asia Pacific School of Logistics (APSL) and Incheon University has established the School of Logistics for Northeast Asia Studies. As part of a more general effort to boost Korea's intellectual 'infrastructure', these initiatives recognize that the success of Incheon's high value added service center would hinge not only on attracting foreign direct investment but also on labor mobility. 
Perhaps the most difficult challenge in a globalized economy is convincing top international 'symbolic analysts' engaged in 'problem solving, problem identifying and strategic brokering activities' that Seoul-Incheon-Pentaport is a 'cool 'place to live and work (Reich, 1992: 177; Florida, 2002). According to Clark Sorenson (2003; 461), attracting highly skilled people - native and overseas Koreans and expatriate nonKoreans - requires attention to the quality of life in Incheon-Seoul for business people, their partners and children and questions of style and taste in urban amenities. He recommends 'unique and aesthetically pleasing motivation-attractions be included in cityplanning', particularly that making use of Incheon's waterfront area. As part of the Incheon FEZ, the Korean government envisages an international quality of living including foreign schools, medical centers and pleasant recreational areas (Jun, 2003).

Thus, Incheon Metropolitan City is seeking to become world-class by becoming a prosperously middle-class city. The management task of any mission-driven taskforce is to provide the businesses with the means to function by capitalizing on Capital Region's strategic location in competition with Beijing, Hong Kong and Shanghai. Clearly, the underlying rationale in Incheon is supply driven; if you build, businesses will come.

\section{PROBLEMS WITH PLACE MARKETING}

Critics of place marketing argue that more evidence is required before it can be assumed that firms locate in cities as a base for export activities and to boost their competitiveness. Even in London and Los Angeles, let alone Incheon, Amin and Thrift (2002) argue that most jobs are in non-basic employment providing goods and services for local consumption and only a few firms are engaged in exports overseas. Productivity and innovation are not derived solely from the export sector but from all sectors of the local economy.

In considering competitive cities, Amin and Thrift (2002) express counter views on the validity of proximity, agglomeration and local networks. Proximity, involving face-toface contact with related firms, is often dwarfed in export performance by urbanization effects derived from the public goods offered by cities and even more so by scale economies. Agglomeration is of no advantage to firms other than those engaged in finance, real estate and insurance, retailing and leisure and a negative if it increases competition for labor. Local networks involving inter-firm trust, cooperation and shared knowledge are often overstated as most firms are more reliant on internal knowledge and technical capabilities.

Similarly, in discussing knowledge cities, Amin and Thrift (2002) seek to counter the hyperbole by stressing that intangible wired connections have neither replaced the tangible person at the end of the line nor the tangible goods that have to be delivered to customers. New high-tech occupations have not supplanted carers, teachers and public servants. Past experience is still of value in production, retailing and distribution and personal services. Thus Amin and Thrift (2002: 63) observe that we need to 'see cities as 
something other than localized economic systems and the forcing houses of knowledge capitalism'.

\section{New Urbanism}

On the basis of these arguments Amin and Thrift (2002) canvass a new urbanism that contradicts the basic tenets of the new localism (Table 12). Rather than the new localism's stress on contrasting the flexible 'space of flows' with fixed urban space, their emphasis is on cities being both local and global. Cities are spatially open and crosscut by many different kinds of mobilities from flows of people to commodities and information. Instead of making a distinction between global as 'remote' and local as 'proximate' there should be recognition that life, including face-to-face contact, now also takes place at a distance.

Table 12. The new urbanism contrasted with the new localism

\begin{tabular}{l|l}
\hline New Urbanism & New Localism \\
\hline \hline Cities local \& global & Space of flows v. urban as space of fixity \\
Here and there & Global as remote v. local as proximate \\
In between & Face to face as small v. distanciated as large \\
\hline
\end{tabular}

Source: Derived from Amin and Thrift (2002: 51).

\section{CONCLUSIONS}

If the argument that 'firms not cities compete' is upheld, the place marketing of SeoulIncheon based on competition with rival cities may not be able to deliver sustainable local economic development. Although cluster programs to strengthen links between local firms have been widely canvassed, they may result in a poor response because Anders Malmberg $(2003 ; 159)$ argues that functional 'industry clusters are rarely confined or contained within narrowly defined local milieus' (italics added). Even firms and institutions within spatial clusters of apparently related activities may not have strong interactions with each other. Indeed, spatial clusters may stem from the importance of specialized labor markets, particularly involving inter-personnel relations.

Similarly, policies designed to improve the city's knowledge base may support business ventures that do not have a strong local foundation. It may be that other actions taken by city leaders to underwrite local economic activity in less obtrusive ways may be more successful. Renewal of green spaces or care for the elderly in different parts of the city may be of little interest to non-Incheon businesses but may have an important impact on local regeneration. The resource base of firms may be better improved by national policies offering credit or tax relief.

Maybe we need to follow Malmberg's (2003: 154) advice and jettison the 
assumption that 'the more local interaction between firms and institutions the better'. Rather than become preoccupied with local interactions the real challenge is to explain how local milieu can tap into sources of specialized knowledge to develop and maintain international competitiveness. On this score we need to give up the preoccupation with the local focus in cluster research and give equal attention to global connections in the processes of social learning and knowledge transfer.

\section{Acknowledgement}

Comments on the text by Dr Sue Rimmer are appreciated.

\section{REFERENCES}

Amin, A. and Thrift, N., 2002, Cities: Reimagining the Urban, Cambridge, Polity Press.

Andretsch, D., 1998, 'Agglomeration and the location of economic activity', Oxford Review of Economic Policy, 14, 2, 18-29.

Burton-Jones, A.,1999, Knowledge Capitalism, Oxford, Oxford University Press.

CI, 2003, Containerisation International Yearbook 2003, London, Informa Ltd.

Castells. M.,1977, The Urban Question, London, Arnold,

Coyle. D., 1997, The Weightless World, Oxford, Capstone.

DOTARS, 2002, Freight Logistics in Australia: An Agenda for Action, Transport and Infrastructure Policy Division. Canberra, Department of Transport and Regional Services.

Flores, F. and Gray, J., 2000, Entrepreneurship and the Wired Life, London, Demos.

Florida, R.L., 2002, The Rise of the Creative Class, Basic Books, New York.

Fujita, M., Krugman, P. and Venables, A.J., 1999, The Spatial Economy: Cities, Regions and International Trade, Cambridge, Mass., MIT Press.

Fujita, M. and Thiesse, J-F., 1996, 'Economics of Agglomeration', Discussion Paper No. 1344, February 1996, London, Centre for Economic Policy Research 53p.

Giddens, A., 1994, Beyond Left and Right, Cambridge, Polity Press.

Glaeser, E., 1998, 'Are cities dying?' Journal of Economic Perspectives, 12, 139-160. 
Harvey, D., 1985, The Urbanisation of Capital, Oxford, Blackwell.

IFEZA, 2004, Incheon Free Economic Zone Authority

http://www.incheon.go.kr/economy/english/is/reason.jsp

IIA, 2004, The Winged City: Incheon International Airport, Incheon, Incheon International Airport.

IMC, 2004, Incheon Vision 21, Incheon Metropolitan City

http://www.incheon.go.kr/inpia/en/main.jsp

Jun Il-Soo, 2003, 'An agenda for the Incheon Free Economic Zone: developing quad ports and quad parks', Journal of International Logistics and Trade, 1,1, 85-105.

KNSO, 2004, Korea Statistical Yearbook 2003, Seoul, Korea National Statistical Office

Kanter, R.M., 1995, Thriving Locally in the Global Economy, New York, Simon Schuster.

Kasteel, E., 2004, 'Recent trends in European logistics', in Korea-The Netherlands Joint Seminar on The Strategy for Developing Incheon into a Logistics Hub in North East Asia, 29 April 2004: 76-120.

Kim, Kyung-Hwan, 2001, Spatial policies towards the Seoul Capital Region http://www.sogang.ac.kr/ kyungkim/homepage

Kotler, P., Hamlin, M.A., Rein, I. and Haider, D.H., 2002. Marketing Asian Places: Attracting Investment, Industry and Tourism to Cities, States and Nations, New York, John Wiley \& Sons.

Krugman, P., 1991, Geography and Trade, Cambridge, Mass., MIT Press.

Krugman. P., 1995, Development Geography and Economic Theory, Cambridge, Mass., MIT Press.

Leadbeater, C., 1999, Living in This Air, London, Viking.

MOST, 2004, Synthetic analysis of R\&D, Ministry of Science \& Technology. http://www.most.go.kr/most/English/activities_03_2.jsp

Malmberg, A., 2003, 'Beyond the cluster-local milieus and global connections', in J. Peck and H. Wai-chung Yeung, Remaking the Global Economy: EconomicGeographical Perspectives, London, Sage, 145-159.

Massey, D., 1984, Spatial Division of Labour, London, Macmillan. 
Miller, M.L. and Kim Sung Gwi, 2004, 'Leisure port development in the Incheon area', Journal of International Trade and Logistics, 2, 1, 5-45.

NBSC, 2003, China Statistical Yearbook, Beijing, China Statistics Press.

O'Connor, P., 2001, The American City and Middle Earth, World Business Chicago. http://www.worldbusinesschicago.com

O'Connor, P., 2003, Chicago: The Center City Capturing a New Geography, World Business Chicago. http://www.worldbusinesschicago.com

Ohmae, K., 1995, The End of the Nation State, New York, The Free Press.

Park, Suk-Cheon, 2004, 'Strategies and implications of air-cargo and logistics hubs: Incheon International Airport', in Korea-The Netherlands Joint Seminar on The Strategy for Developing Incheon into a Logistics Hub in North East Asia, 29 April 2004, 49-73.

Park, Yonghwa and Kim, Byung-Jung, 2002, Evaluating the competitive status of Incheon International Airport among other major Asian airports.

http://www.koti.re.kr/project/Coop.nsf

Pierce, N., 1993, How Urban America Can Prosper in a Competitive World, Washington, D.C., Seven Locks Press.

Piore, M. and Sable, C., 1984, The Second Industrial Divide, New York, Basic Books.

Porter, M.E., 1990, The Competitive Advantage of Nations, New York, The Free Press.

Porter, M., 1995, 'The competitive advantage of the inner city', Harvard Business Review, May-June, 53-71.

Quah, D.T., 1997, 'The weightless economy: Nintendo and heavy metal'. Centre Piece, London, Centre for Economic Performance, London School of Economics.

Reich, R.B., 1992, The Work of Nations: Preparing Ourselves for $21^{\text {st }}$ Century Capitalism, first ed. 1991, New York, Vintage Books.

Rimmer, P.J. and Chang, Young-Tae, 2004, Incheon Pentaport - five ports in one: seeking its conceptual underpinning, unpublished paper presented at the Three Consecutive Events Celebrating 50th Anniversary of INHA University, 27-29 April 2004.

Rimmer, P.J. and Jun Il-Soo, 2000, 'A vision for an integrated transport system in 
Norheast Asia', in Il-Soo Jun (ed.), Creating a Regional Transportation System in Northeast Asia, Seoul, The Korea Transport Institute: 363-415.

SB, 2004, Japan Statistical Yearbook, Tokyo, Statistics Bureau. Ministry of Public

Management, Home Affairs, Posts and Telecommunications.

Sennett, R., 1998, The Corrosion of Character, New York, Noton.

Scott, A., 1988, Metropolis, Los Angeles, University of California Press.

Sorenson, C.W., 2003, 'Cultural dimensions of quality of life for expatriate business talent in Korea', Korea Observer: A Quarterly Journal, 34, 3, 461-483.

Storper, M., 1997, The Regional World, New York, Guilford Press.

TGI, 2003, Telegeography 2003: Global Telecommunications Traffic Statistics and Commentary, Washington, D.C., Telegeography Inc.

UN, 2001, World Urbanization Prospects: The 1999 Revision, New York, United Nations.

Urban Development Authority, 2003, Creative City: The Land of Opportunity - Incheon. Incheon, Incheon Metropolitan City.

Yusuf, S., Wu, W. and Evenett, S. (eds), 2000, Local Dynamics in an Era of Globalization, Washington, D.C., The International Bank for Reconstruction and Development/The World Bank. 